SAKAI SAMBAYAN — Jurnal Pengabdian kepada Masyarakat

\title{
APLIKASI MESIN PEMBUATAN PUPUK ORGANIK GRANUL (POG) PADA KELOMPOK TANI PANCA KARYA DESA SINAR SARI KECAMATAN KALIREJO LAMPUNG TENGAH
}

\author{
Warji $^{1^{*}}$, Tamrin ${ }^{1}$, Budianto Lanya ${ }^{1}$ \\ ${ }^{1}$ Jurusan Teknik Pertanian, Fakultas Pertanian, Universitas Lampung, Bandar Lampung \\ Jl. Prof. Sumantri Brojonegoro No.1 Bandar Lampung 35145 \\ Penulis Korespodensi : warji1978@fp.unila.ac.id; warji1978@gmail.com
}

\begin{abstract}
Abstrak
Kelompok Tani Panca Karya di Desa Sinar Sari Kecamatan Kalirejo telah lama memanfaatkan pupuk organik untuk memupuk sawah dan ladang mereka, bahkan menurut penuturan salah satu anggota kelompok tani bahwa secara turuntemurun mereka memanfaatkan pupuk kandang (kotoran hewan) dan pupuk kompos (seresah dan sisa-sisa tanaman pertanian) untuk menyuburkan tanah pertanian. Kelompok Tani Panca Karya telah berkomitmen untuk memproduksi dan mengembangkan pupuk organik padatan menjadi Pupuk Organik Granul (POG). Permasalahan utama yang mereka dihadapi adalah cara membuat POG yaitu proses pembuatan butiran, selama ini butiran dibuat dengan menggunakan nampan dengan cara menginteri, dimana kapasitasnya sangat terbatas dan ukurannya tidak seragam. Sementara proses pembuatan butiran dapat menggunakan granulator, salah satunya adalah granulator yang telah dihasilkan oleh Jurusan Teknik Pertanian Universitas Lampung. Kapasitas mesin granulator ini sekitar 100 kg/jam, butiran yang dihasilkan berbentuk bulat dan seragam. Oleh karena itu pada pengabdian ini diaplikasikan mesin pembuat butiran (granulator) tersebut. Pelaksanaan pengabdian pada Kelompok Tani Panca Karya berjalan dengan baik. Mesin granulator POG dapat diaplikasikan pada kelompok tani (mitra) dengan baik dan pengetahuan mitra secara keseluruhan meningkat sekitar $65 \%$ yaitu dari 21,67\% menjadi $86,67 \%$. Kegiatan pengabdian serupa sangat diharapkan oleh mitra, mereka menginginkan adanya introduksi teknologi yang dihasilkan oleh Perguruan Tinggi, secara khusus mitra menginginkan introduksi peletting benih dan alsintan kedelai.
\end{abstract}

Kata kunci: butiran, granulator, pupuk organik, pupuk organik granul.

\section{Pendahuluan}

Kelompok Tani Panca Karya berada di Desa Sinar Sari Kecamatan Kalirejo Kabupaten Lampung Tengah yang berjarak $\pm 75 \mathrm{~km}$ dari Badar Lampung (Universitas Lampung). Kelompok tani ini memiliki anggota sekitar 30 orang, dimana rata-rata berprofesi sebagai petani tanaman musiman (padi, palawija dan sayursayuran). Anggota Kelompok Tani Panca Karya telah lama memanfaatkan pupuk organik untuk memupuk sawah dan ladang mereka, bahkan menurut penuturan salah satu anggota kelompok bahwa secara turun-temurun mereka memanfaatkan pupuk kandang (kotoran hewan) dan pupuk kompos (seresah dan sisa-sisa tanaman pertanian) untuk menyuburkan tanah pertanian (Hasil wawancara langsung oleh Tim Pengabdian pada bulan November 2013).

Sementara itu Kelompok Tani Panca Karya telah berkomitmen untuk memproduksi dan mengembangkan pupuk organik, baik untuk keperluan sendiri maupun untuk bisnis. Perlu diketahui bahwa selama ini pupuk organik yang dibuat atau diproduksi masih digunakan sendiri oleh anggota kelompok, namun ada harapan kelompok tani bahwa usaha pembuatan pupuk organik ini dapat menjadi usaha/bisnis yang dapat menghasilkan keuntungan bagi anggota kelompok.

Dalam upaya memproduksi pupuk organik ini Kelompok Tani Panca Karya telah mengadakan alat pencacah bahan kompos, penghancur dan pengayak bahan kompos melalui bantuan Pemerintah Daerah dan Lembaga lainnya (Gambar 1). Peralatan-perlatan ini dipakai untuk membuat pupuk organik padat (berupa cacahan halus bahan organik yang berasal dari sisa-sisa tanaman dan kotoran hewan). Seiring dengan berkembangnya teknologi bermunculan jenis pupuk organik baru, salah satunya Pupuk Organik Granul (POG) yaitu pupuk organik yang berbentuk butiran-butiran atau 
bulatan kecil dari bahan-bahan pupuk organik halus. POG ini bentuknya menyerupai pupuk kimia dan aplikasinya lebih mudah dibandingkan dengan pupuk organik padatan. POG ini secara ekonomis harganya lebih mahal dibandingkan dengan pupuk organik padatan. Peluang inilah yang menjadikan Kelompok Tani Panca Karya yang diketuai oleh Bapak Agus menginginkan mengembangkan usaha pembuatan POG.
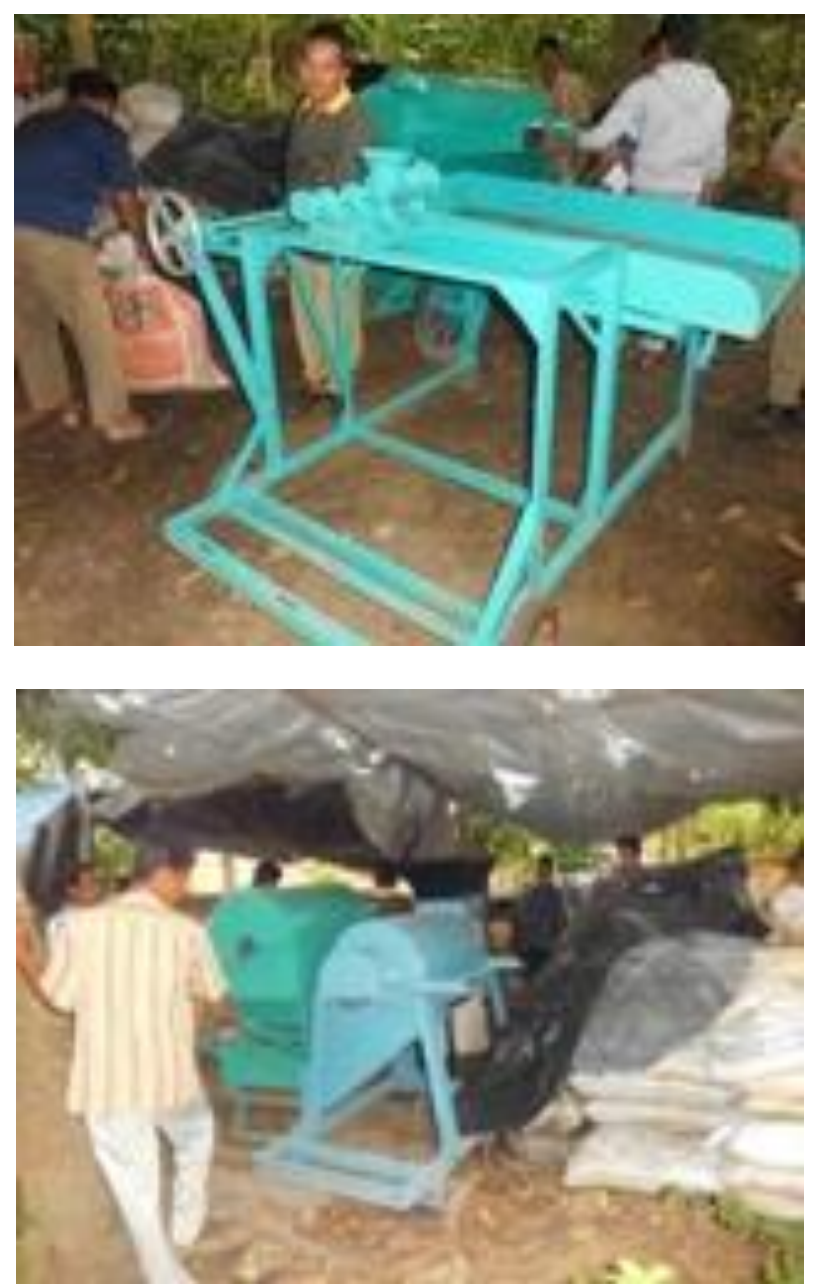

Gambar 1. Peralatan yang telah dimiliki oleh Kelompok Tani Panca Karya

Kendala utama yang dihadapi oleh kelompok tani dalam membuat POG adalah proses pembuatan butiran (granul) pupuk organik, sehingga sangat relevan diaplikasikan mesin granulator pembuat POG. Hal ini sangat diharapkan oleh Kelompok Tani Panca Karya yang disampaikan pada saat penjajakan program pengabdian yang dilakukan oleh Tim Pengabdian pada bulan November 2013.

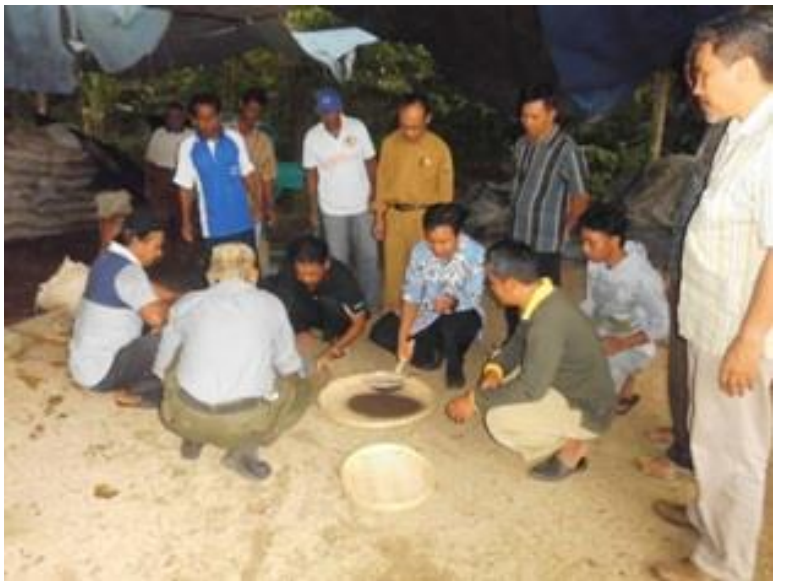

Gambar 2. Proses penjajakan kerjasama aplikasi granulator (mencoba membuat pupuk organik granul secara manual)

Proses pembuatan butiran POG pada Kelompok Tani Panca Karya Desa Sinar Sari selama ini dilakukan dengan menggunakan nampan dengan cara me-nginteri, yaitu membuat butiran dari bahan yang halus semisal tepung yang diberi air dan dicampur merata kemudian dimasukkan ke nampan dan nampanya diputar dengan tangan, dimana kapasitasnya sangat terbatas dan ukurannya tidak seragam.

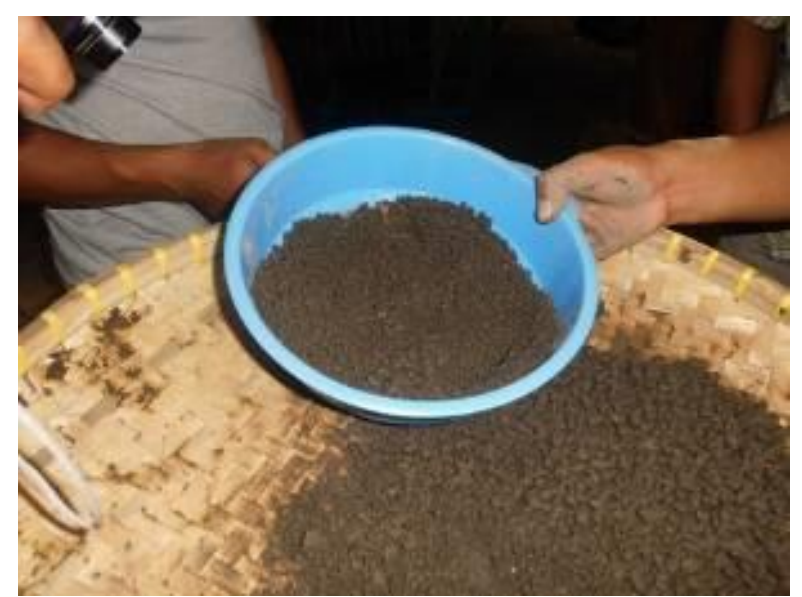

Gambar 3. Pupuk organik granular tradisional yang dibuat oleh Kelompok Tani Panca Karya

Sementara proses pembuatan butiran dapat menggunakan granulator, salah satunya adalah granulator yang telah dihasilkan oleh Jurusan Teknik Pertanian Universitas Lampung. Kapasitas mesin granulator ini dapat mencapai $100 \mathrm{~kg} / \mathrm{jam}$ dengan butiran yang dihasilkan berbentuk bulat dan seragam. Oleh karena itu pada pengabdian ini diaplikasikan mesin pembuat butiran (granulator) yang telah dihasilkan oleh Jurusan Teknik 
Pertanian, Fakultas Pertanian, Universitas Lampung (Warji, 2009; Warji et al., 2009; Warji et al., 2018).

Mesin ini bekerja berdasarkan gaya sentripetal dan terbentuknya butiran akibat adanya putaran. Bahan kompos yang sudah dihaluskan yang diumpankan pada bidang pembuat butiran membentuk butiran-butiran/agregat akibat gerakan berputar. Mekanisme ini terjadi seperti bola salju, makin lama butiran yang terbentuk makin besar. Pada diameter tertentu butiran akan keluar dari bidang pembuat butiran akibat terhalang oleh bidang pengatur besar diameter. Butiran-butiran POG yang terpental keluar mengelompok pada satu arah sehingga pada arah ini diletakkan penampung hasil pembentukan butiran.

Butiran POG yang terbentuk kondisinya padat, tidak mudah remah (hancur) sehingga dapat dikatakan bentuknya kompak, butiran ini jika dibandingkan dengan butiran hasil nginteri menggunakan nampan, hasilnya lebih padat dan kompak karena pada proses pembentukan butiran dengan menggunakan mesin ini butiran berputar pada bidang yang lebih luas, lintasannya lebih panjang dan gaya sentripetalnya lebih besar dibandingkan nginteri dengan menggunakan nampan.

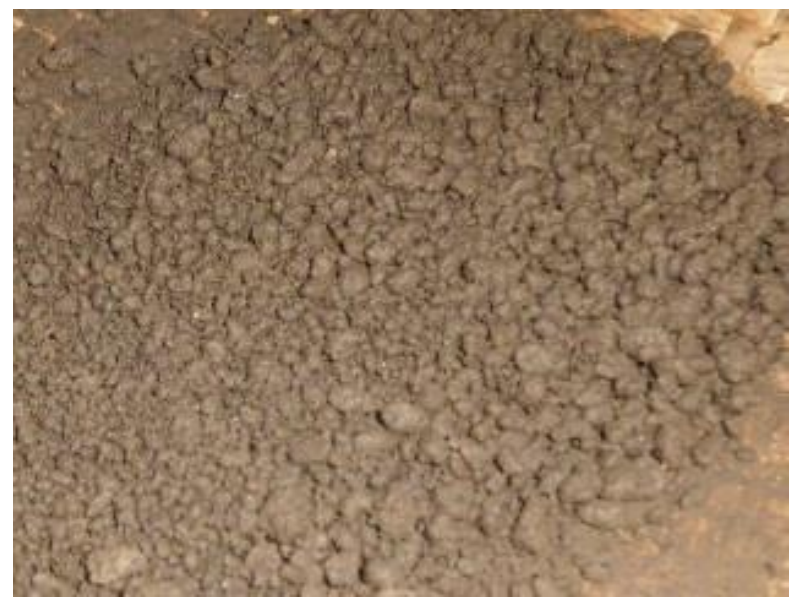

Gambar 4. Butiran POG basah yang dihasilkan Kelompok Tani Panca Karya

Pupuk organik granul merupakan salah satu jenis pupuk organik. Pupuk ini bentuknya butiranbutiran yang berdiameter antara 2 sampai $5 \mathrm{~mm}$. Pupuk ini banyak dimanfaatkan untuk memupuk tanaman pertanian, tanaman hias dan pertamanan. Pupuk organik granul ini dibuat dari hancuran sisasisa tanaman, kotoran hewan dan unsur-unsur hara tambahan semisal dolomit, organo fospor dan lain- lain, serta limbah biogas juga dapat dimanfaatkan sebagai bahan campuran pembuatan POG (Argo et al., 2012), bahkan hasil penelitian Yanti et al. (2013) menyimpulkan bahwa sampah pekarangan dapat dijadikan sebagai pupuk organik ini.

Pupuk organik padatan yang dicampur dengan Pupuk Organik Cair (POC) sangat baik diaplikasikan pada tanaman untuk meningkatkan pertumbuhan tanaman (Supartha et al., 2012). Pembuatan pupuk organik granular tidak terlalu sulit kalau menggunakan mesin granular, dimana semua bahan organik yang telah dihancurkan ditambahkan unsur hara seperti dolomit dan lainlain cukup dimasukkan ke dalam mesin granular dan diputar beberapa saat maka akan terbentuk pupuk organik granul (Isropi, 2009).

Kegiatan pengabdin ini bertujuan mengaplikasikan mesin granulator (pembuat butiran) pada pembuatan POG pada Kelompok Tani Panca Karya di Desa Sinar Sari Kecamatan Kalirejo, Lampung Tengah. Pengabdian ini juga memberikan wawasan tentang komposisi dan teknis pembuatan POG, serta memberikan wawasan tentang pengemasan POG yang dihasilkan.

Manfaat kegiatan adalah Kelompok Tani Panca Karya dapat memproduksi POG dengan kapasitas yang lebih besar dibandingkan dengan cara manual dan menambah wawasan tantang komposisi dan teknis pembuatan POG. Sehingga program pengabdian ini dapat meningkatkan kapasitas produksi dan kualitas POG yang pada gilirannya dapat dipasarkan secara luas. Pemasaran yang luas diharapkan dapat meningkatakan pendapatan dan kesejahteraan anggota Kelompok Tani Panca Karya. Kegiatan pembuatan POG ini juga dapat menjadi percontohan bagi kelompok tani yang lain yang ada di Kecamatan Kalirejo mengingat pertanian organik berkembang di Kecamatan Kalirejo.

\section{Bahan dan Metode}

\section{A. Kerangka dan realisasi pemecahan masalah}

Permasalahan proses pembuatan butiran POG yang dihadapi Kelompok Tani Panca Karya diselesaikan dengan melakukan perancangan mesin granulator (pembuat butiran) dalam pembuatan POG dan memberikan wawasan (penyuluhan) tentang komposisi dan teknik pembuatan POG. 


\section{B. Khalayak sasaran}

Khalayak sasaran kegiatan pengabdian ini adalah Kelompok Tani Panca Karya yang berada di Desa Sinar Sari Kecamatan Kalirejo Kabupaten Lampung Tengah Propinsi Lampung yang beranggotakan sekitar 30 orang, dimana rata-rata mereka adalah petani tanaman musiman yang telah lama memanfaatkan pupuk organik sebagai pendamping pupuk kimia. Kegiatan penjajakan kerjasama program pengabdian ini disajikan pada Gambar 6.

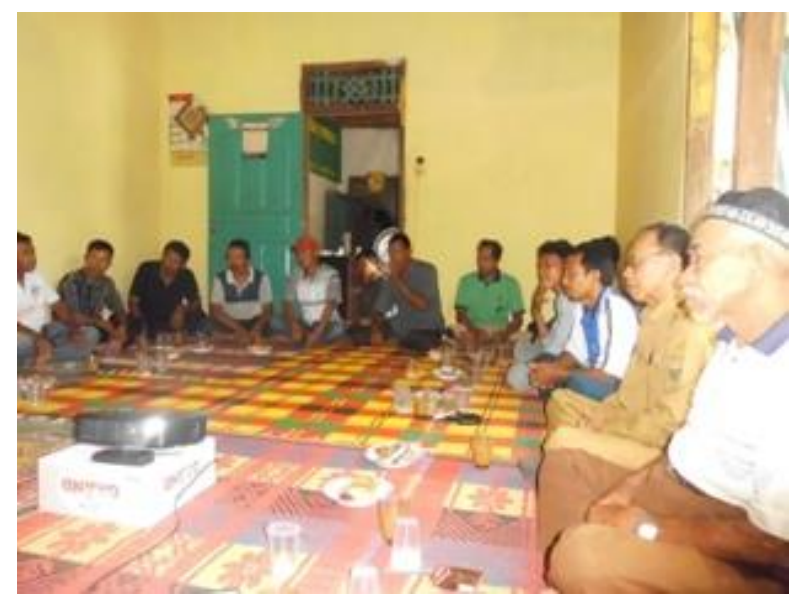

Gambar 5. Penjajakan kegiatan pengabdian dengan anggota Kelompok Tani Panca Karya

\section{Metode pengabdian}

Metode pengabdian berupa aplikasi mesin granulator (pembuat butiran) dalam pembuatan POG dan memberikan wawasan (penyuluhan) tentang komposisi dan teknik pembuatan POG.

\section{Rancangan evaluasi}

Evaluasi keberhasilan program diukur dengan menggunakan instrumen kuisioner. Kuisioner diberikan sebelum aplikasi teknologi dan setelah aplikasi teknologi. Setelah kegiatan berakhir skor pada kuisioner diolah dan dan dianalisis sehingga dapat disajikan persentase keberhasilan kegiatan pengabdian ini. Evaluasi juga dilakukan terhadap kapasitas produksi sebelum dan sesudah adanya aplikasi mesin granulator.

\section{Hasil dan Pembahasan PKM}

\section{A. Pelaksanaan kegiatan pengabdian}

Pengabdian kepada masyarakat ini berjalan dengan baik dan sesuai dengan rencana. Proses yang pertama dilakukan adalah perumusan masalah bersama mitra. Setelah disepakati, masalah yang diselesaikan adalah cara membuat pupuk organik granul atau dikenal dengan singkatan POG dengan menggunakan granulator. Proses perumusan masalah bersama mitra disajikan dalam Gambar 7, Sementara di Bengkel Mekanisasi Pertanian, Jurusan Teknik Pertanian dilakukan perancangan dan manufacturing mesin granulator sesuai yang dibutuhkan oleh kelompok tani, proses rancang bangun disajikan pada Gambar 8, sementara granulator yang sudah jadi dan siap diaplikasikan untuk membuat pupuk POG disajikan pada Gambar 11.

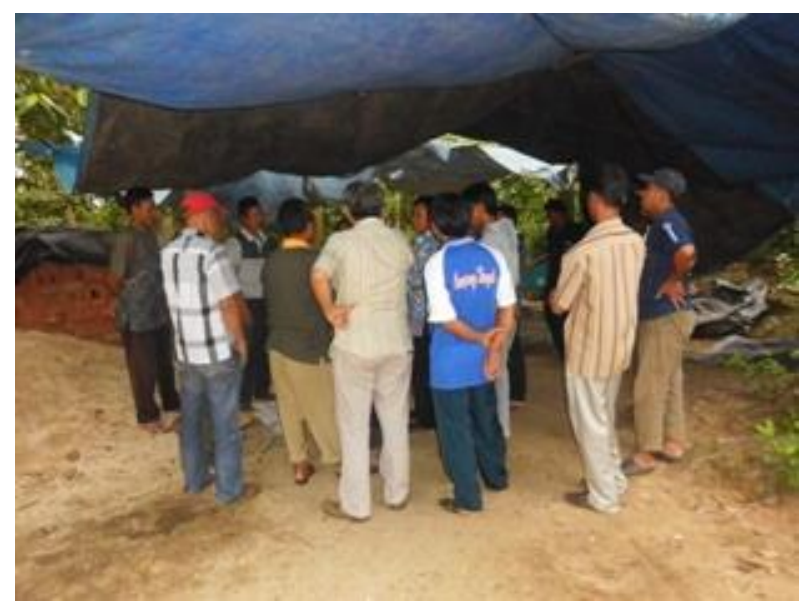

Gambar 6. Perumusan masalah bersama mitra

Tahap selanjutnya dalam proses pengabdian masyarakat ini adalah melakukan pelatihan tentang cara pembuatan pupuk kompos granul (POG), proses ini ditunjukkan pada Gambar 9 dan Gambar 10, namun sebelum praktek pembuatan POG, terlebih dahulu dilakukan penjelasan tentang POG. Penjelasan yang dikemas dalam bentuk pemberian materi secara singkat meliputi cara pembuatan POG, komposisi POG dan pengeringan (Gambar 12). Pengeringan POG dapat dilakukan secara bacth (Nainggolan et al., 2013) dan dengan tipe rak (Warji et al., 2009; Asmara dan Warji, 2010; Sari et al., 2013). Materi tersebut disampaikan oleh Warji, S.TP., M.Si, Ir. Budianto Lanya, M.T., dan Dr. Ir. Tamrin, M.S. Semua proses ini dapat berjalan lancar, sehingga target pelatihan dapat tercapai dengan baik. 

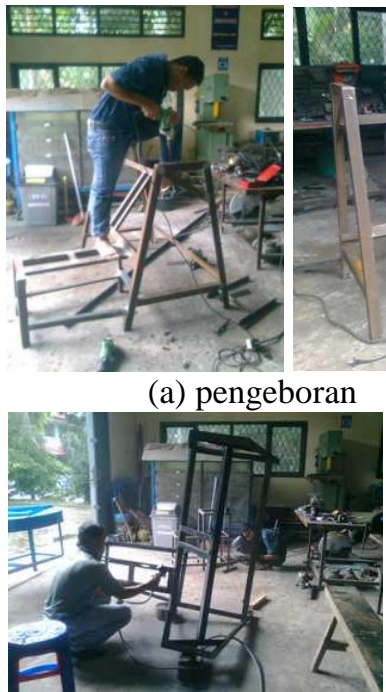

(c) pengecatan

Gambar 7. Proses rancang bangun granulator

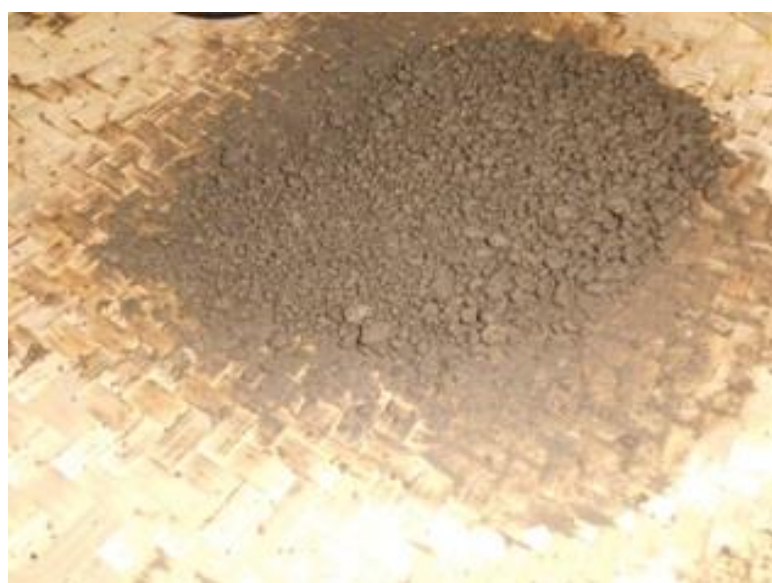

Gambar 8. Proses pembuatan POG secara manual

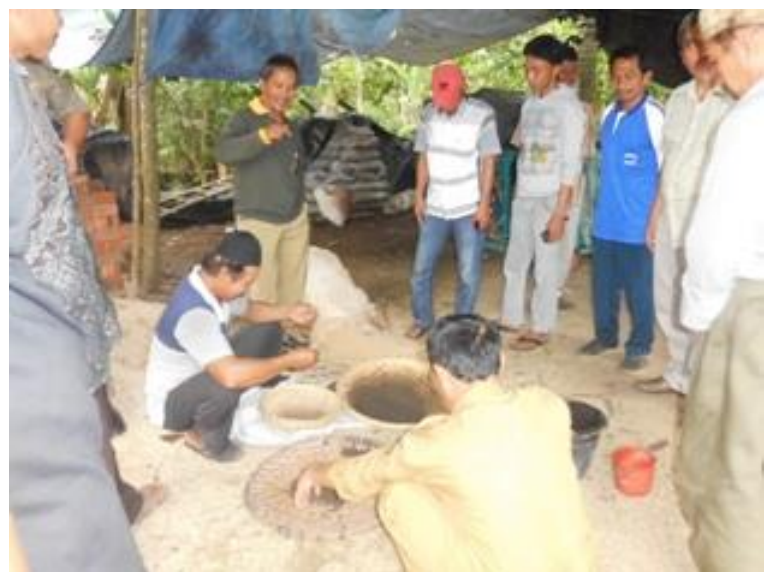

Gambar 9. Peserta mengikuti praktek pembuatan POG secara manual

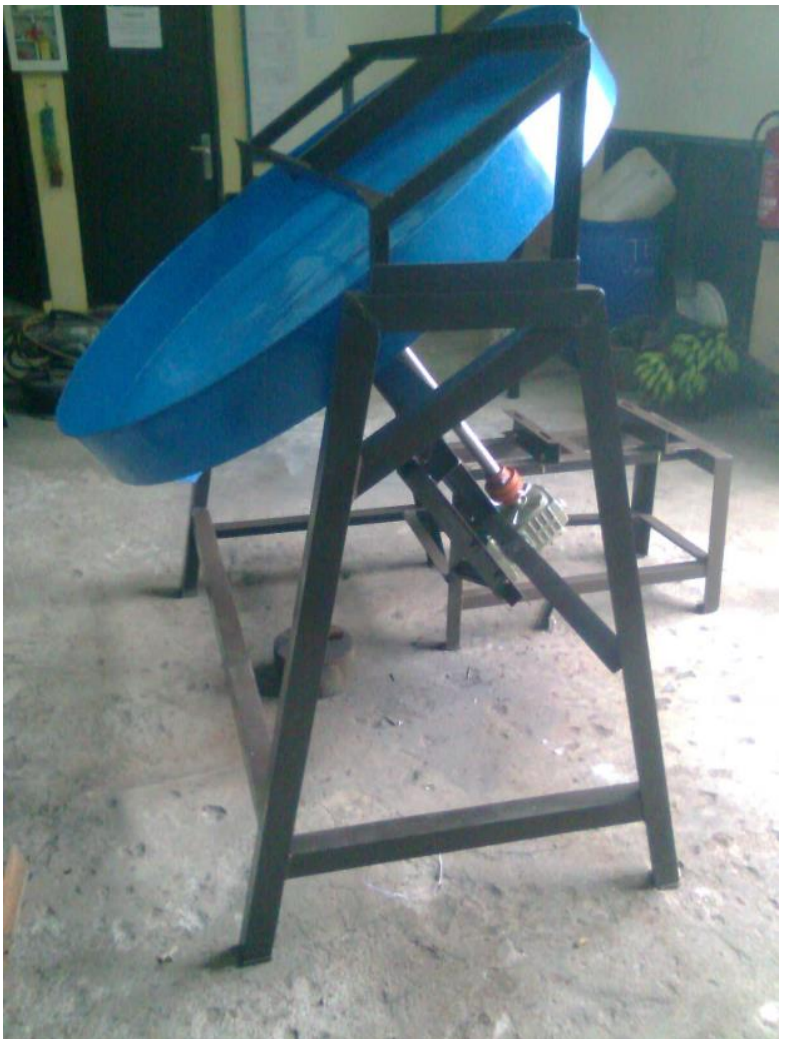

Gambar 10. Granulator siap diaplikasikan untuk membuat pupuk POG

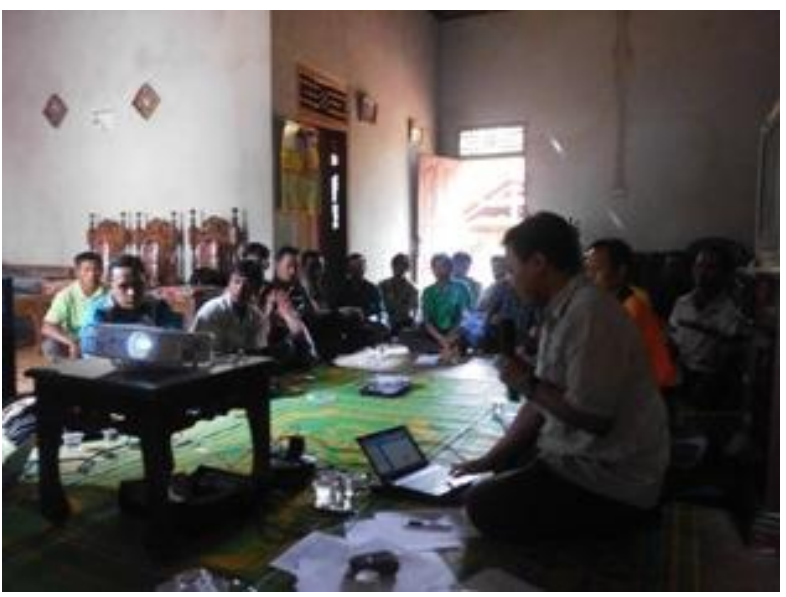

Gambar 11. Penyampaian materi oleh Tim

\section{B. Evaluasi pelaksanaan pengabdian}

Berdasarkan evaluasi terhadap responden pada kegiatan pengabdian ini terdapat peningkatan pengetahuan responden terhadap POG. Pengetahuan responden sebelum pengabdian mencapai 21,67\%, pengetahuan ini terutama pengetahuan tentang POG, jenis pupuk dan pengalaman tentang pembuatan POG, sebagian responden pernah mendengar tentang POG, namun belum mengetahui secara detail, baik bahan 
asalnya, proses pembuatnnya serta pemanfaatannya. Sementara skor pengetahuan mereka meningkat menjadi $86,67 \%$ setelah adanya pelatihan pada program pengabdian ini, peningkatan pengetahuan disajikan pada Gambar 13.

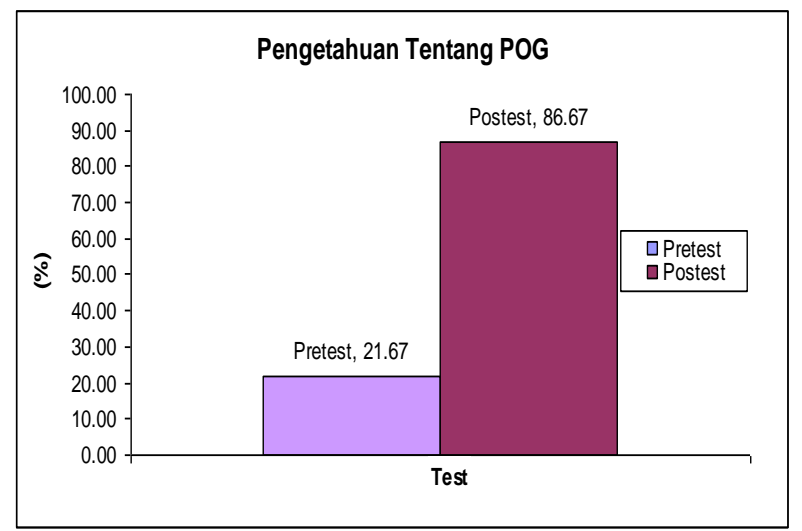

Gambar 12. Rata-rata pengetahuan responden tentang POG

Sementara ketertarikan mitra untuk mengaplikasikan mesin granulator POG sangat tinggi, sebagaimana disajikan dalam Gambar 14. Semua peserta pelatihan menginginkan dapat menggunakan granulator POG.

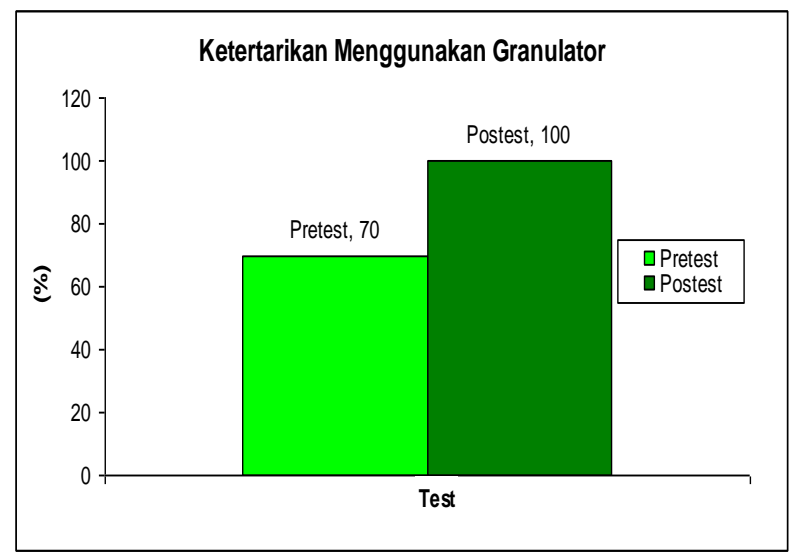

Gambar 13. Ketertarikan responden terhadap granulator POG

Responden juga mengharapkan kegiatan pengabdian serupa dilakukan secara kontinyu, mereka merasa mendapat manfaat dan mendapat peningkatan pengetahuan. Mitra juga tertarik dan ingin dilakukan introduksi teknologi yang dihasilkan di Perguruan Tinggi, khususnya aplikasi mesin peletting benih dan alat dan mesin budidaya kedelai. Data perlunya pengabdian disajikan Gambar 15.

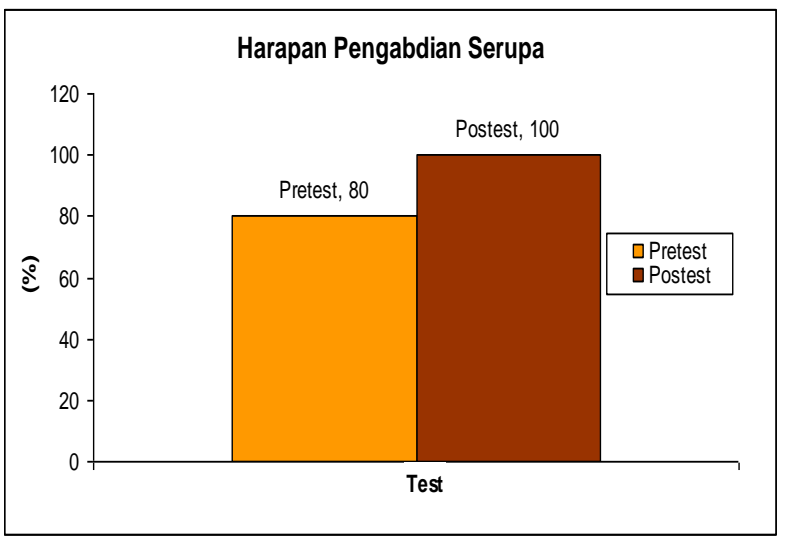

Gambar 14. Harapan pengabdian serupa

\section{Kesimpulan dan Saran}

A. Kesimpulan

Pelaksanaan pengabdian berjalan sesuai dengan rencana, mesin granulator POG dapat diaplikasikan dengan baik. Sementara pengetahuan mitra secara keseluruhan meningkat sekitar $65 \%$, yaitu meningkat dari $21,67 \%$ menjadi $86,67 \%$.

\section{B. Saran}

Kegiatan pengabdian seperti ini sangat diharapkan oleh mitra, mereka menginginkan adanya intrioduksi teknologi yang dihasilkan oleh Perguruan Tinggi. Secara khusus mitra menginginkan adanya introduksi peletting benih dan alsintan kedelai.

\section{Ucapan Terima Kasih}

Ucapan terima kasih disampaikan kepada Lembaga Penelitian dan Pengabdian Kepada Masyarakat (LPPM) Universitas Lampung, KEMENRISTEK DIKTI yang telah membiayai kegiatan pengabdian ini melalui dana DIPA Universitas Lampung Tahun Anggaran 2014 dengan Nomor Kontrak: 455.14/UN26/9/PM/2014. Terima kasih juga disampaikan kepada Kelompok Tani Panca Karya khususnya kepada Bapak Agus sebagai ketua Kelompok Tani serta terima kasih kepada Bapak Muchamad Suud selaku Penyuluh BP3K Kecamatan Kalirejo Kabupaten Lampung Tengah atas kerjasamanya sehingga pengabdian ini dapat terlaksana dengan baik.

\section{Daftar Pustaka}

Argo, D. B., Lutfi, M., \& Suherman. (2012). Optimasi Penambahan Unsur Hara NPK pada Limbah Biogas dan Kompos Kambing sebagai Bahan Pembuatan Pupuk Organik Granul dengan 
Menggunakan Program Linear. Jurnal Teknologi Pertanian, 13(1), 27-33.

Asmara, S., \& Warji, W. (2010). Kinerja Pengeringan Chip Ubikayu. Jurnal Keteknikan Pertanian, 24(2), 75-80.

Isropi. (2009). Praktek Membuat Pupuk Organik Granul. http://isroi.com/2009/03/04/ praktek-membuatpupuk-organik-granul/ [diakases : tanggal 27 Februari 2013]

Nainggolan, S. R. M., Tamrin, T., Warji, W., \& Lanya, B. (2013). Uji Kinerja Alat Pengering Tipe Batch Skala Lab untuk Pengeringan Gabah dengan Menggunakan Bahan Bakar Sekam Padi. Jurnal Teknik Pertanian Lampung, 2(3), 161-172.

Sari, I. N., Warji, W., \& Novita, D. D. (2014). Uji Kinerja Alat pengering Hybrid Tipe Rak pada Pengeringan Chip Pisang Kepok. Jurnal Teknik Pertanian Lampung, 3(1), 59-68.

Supartha, I. N. Y.,Wijana, G., \& Adnyana, G. M. (2012). Aplikasi Jenis Pupuk Organik pada
Tanaman Padi Sistem Pertanian Organik. EJurnal Agoekoteknologi Tropika, 1(2).

Warji, W., Novita, D. D., \& Suharyatun, S. (2018). Aplikasi Teknologi Granulator pada Kelompok Usaha Beras Analog di Bandar Surabaya Lampung Tengah. Jurnal Sakai Sambayan, 3(1), 72-79.

Warji. 2009. Rekayasa Mesin Pembuat Butiran Tiwul. Jurnal Enjiniring Pertanian, 8(2), 91-98.

Warji., Asmara, \& Suharyatun, S. (2009). Rancang Bangun Produksi Tiwul Instan dalam Mendukung Keahanan Pangan Nasional. Lembaga Penelitian. Unila. Lampung.

Yanti, Y. A., Indrawati, \& Refilda. (2013). Penentuan Kadar Unsur Hara Mikro $(\mathrm{Zn}, \mathrm{Cu}$ dan $\mathrm{Pb})$ di dalam Kompos yang Dibuat dari Sampah Tanaman Pekarangan dan Aplikasinya pada Tanaman Tomat. Jurnal Kimaa Unand, 2(1). 